\title{
A Return to Multilateralism-China's Reform and Opening Up in a Historical Setting
}

\author{
Ronnie C. Chan
}

\begin{abstract}
The patterns of history provide important insights into current global political and economic trends. The ebb and flow of history illustrate that pivotal points create profound change. In the twentieth century, the obvious turning points were the two world wars. The emergence of China as an economic powerhouse, thanks to her 'reform and opening-up' policy, should be considered as the other significant event in the last century that is having a lasting impact in this century. Coupled with the United States' retreat to isolationism, the world is likely to return to a more multilateral world order.
\end{abstract}

Keywords Patterns of history $\cdot$ Ebb and flow of history $\cdot$ Pivotal points create profound change - The 'Reform and Opening up' of China - U.S. isolationism • China does not seek hegemony

\section{Let's Learn from History}

Before we look to the future ${ }^{1}$, we should always review history. As Winston Churchill once said, "those who fail to learn from history are condemned to repeat it." 2 In this spirit, let's look at the two significant events that shaped the twentieth century. The first that comes to mind would be the two world wars, which had two profound effects: the invention of weapons capable of wiping out the entire human race, and a new world order ushered in after 1945 and was dominated by the United States. The other significant event of the twentieth century would be China's emergence as an economic powerhouse, thanks to her 'reform and opening-up' policy. It would

R. C. Chan $(\bowtie)$

Asia Society Hong Kong Center, Hong Kong, China

${ }^{1}$ This article was written by the editing team of CCG based on the speech delivered by Ronnie C. Chan at the 2018 CCG Annual Conference in Beijing on May 20, 2018.

${ }^{2}$ The original quote came from George Santayana (1863-1952) the Spanish-born philosopher and critic: The Life of Reason (1905) vol. 1, ch. 12 which reads: "Those who cannot remember the past are condemned to repeat it!" In a 1948 speech to the House of Commons, Winston Churchill changed the quote slightly when he said (paraphrased), "those who fail to learn from history are condemned to repeat it." 
be worthwhile to look further into the past to see how China's current trajectory of 'reform and opening-up' fits in the ebb and flow of history.

Let us examine the past few centuries and choose two major events from each century that shaped the course of history. Starting with the fourteenth century, we saw the Black Death and the Renaissance. Then came the Conquest of Istanbul by the Ottoman Empire in the fifteenth century, thereby controlling the most critical location to control the trade routes between Europe and Asia. The outcome of that assault ultimately sparked Western Europe to send Christopher Columbus and other explorers to search for alternate sea routes to Asia, and this eventually led to the other major event of that century - the discovery of the Americas in 1492. Moving to the next century, the Reformation would be regarded as one of the two major events of the sixteenth century. This upheaval also served as a catalyst for the rise of the British Empire and her victory over the Spanish Armada in 1588. In the middle of the seventeenth century, the signing of the Treaty of Westphalia in 1648 marked the beginning of the notion of the 'nation state', and this was followed by the shameful chapter of colonialism. By the 18th century, colonialism gave way to the birth of the United States and the dawn of the Industrial Revolution. The nineteen century saw the dominance of imperialism and the United States surpassing the United Kingdom as the largest economy in the world by the 1890s. In the twentieth century, as mentioned above, there were the two world wars and the rise of China. The latter is especially important because, coupled with the United States' retreat to isolationism, the rise of China might signal a possible return to a more multilateral world order.

\section{From Multilateral to Unilateral and Back Again}

If we look at history from another perspective, we can say that some 1,400 years prior to 1945 was a period of chaotic multilateralism, while from 1945 onward, the world transitioned to a bilateral system dominated by the United States and the Soviet Union (U.S.S.R.). This period only lasted around 45 years until 1991 with the dissolution of the U.S.S.R., phasing into an essentially unilateral world dominated solely by the United States and lasting through to the present day. The increasing brevity of these periods seems to indicate that the ebb and flow in history are oscillating faster and lasting shorter. Can the current period of unilateralism sustain? Clearly, the answer is not, because of two reasons: the re-emergence of China and the retreat of the United States to isolationism.

The main reason for the United States' penchant toward isolationism is simplefundamentally, it has always been an isolationist. The root of that characteristic is a principle upon which the young country was founded. Many events in American history pointed to this fact, for example, the Monroe Doctrine and Manifest Destiny of the nineteenth century, the Roosevelt Corollary of not joining the League of Nations, and the trade barriers of the 1920s. It was really only after World War II when the United States finally, and reluctantly, took center stage in global affairs. But even 
then, she was often delinquent in her United Nations dues, and has withdrawn from multilateral organizations.

History has shown that China is no stranger to isolationism. After World War II, with the United States being forced to step onto the global center stage and given the real and perceived threats of the then U.S.S.R., much of the world embarked on a long process of globalization. Only the Communist bloc was left out, while tremendous wealth was created by and for the so-called free world. Hong Kong benefited immensely, while mainland China chose isolationism.

China should have known better, but ideology got in the way. When this ancient country began to close herself off from the rest of the world in the early fifteenth century, during the Ming Dynasty, she began to wane. Attempts to open up failed, like the reforms in the early twentieth century. Subsequent civil wars and the Japanese invasion in 1931 spelled her doom. Chairman Mao's efforts to engage the United States in the late 1940s were rebuffed and the Korean War in the early 1950s sealed the country's fate to isolationism.

Leaders in Beijing knew that they were missing out, and it was not until U.S. President Richard Nixon, with the help of his then National Security Advisor Dr. Henry Kissinger, that China was given an opportunity in the early 1970s to reengage with the Western world. To be sure, the United States had her own need for rapprochement - to contain the then U.S.S.R. Whatever the case, Beijing gladly took up the offer. This laid the foundation for the country to open her doors in 1978, which led to her prosperity of the past 40 years.

Meanwhile, the world was caught by surprise in the early 1990s when the U.S.S.R. collapsed. It gave a boost to globalization, as technologies formerly used for military purposes could now be commercialized. Modernization went to newer heights never seen before. Just consider how the smartphone alone has changed the world. The United States was free to mold the world in her own image and became her selfanointed benevolent hegemon. This enabled the United States to lead her allies and friends to form the institutions and mechanisms that shaped the current world order.

Today, the retreat of the United States to isolationism does not spell the end of the world but merely a phase in the course of history. It is in this context that we should objectively revisit history to better understand current affairs. After all, China has absolutely no intention of becoming a new global hegemon nor even be part of a "G2" with the United States. The best scenario for China would be to foster cooperation under the G20 framework, but this is not just up to China. While the United States retreats to isolationism, the world is likely to return to multilateralism.

\section{What does China's Rise Mean to the World?}

In hindsight, there were a few cultural and historic factors that played a role in China's rise, without which the miracle we see today could not have happened. This is why her emulation elsewhere in the world is doubtful. They may not have sufficient amounts of the right mix of factors. First, Confucian ethics was critical-hard work, 
family cohesion, and an emphasis on education. The resulting high savings rates and the willingness for delayed gratification were also absolutely necessary. The unimaginable suffering, both physical and psychological, endured during the decadelong Cultural Revolution instilled in the average citizen a powerful desire for stability, if not prosperity.

Having said that, in my opinion, the most significant impact of China's rise is it paved the way to a new world order of co-existence and co-prosperity between the East and the West. The last time this happened was around 2,000 years ago when the Roman Empire dominated Europe, while the prosperous Han Dynasty of China flourished in Asia. Of course, science and technology back then were not as advanced as they are today, hence no extensive contact between the two peoples, but it was an era in history where two major powers had co-existed and co-prospered. Thereafter, Europe had its share of rise and decline: the fall of the Roman Empire in fifth century, Renaissance in the fourteenth century, Industrial Revolution in the nineteenth century, to name just a few. In contrast, China was basically on the wane for centuries, most notably in the past 200 years.

In the current era of burgeoning co-prosperity of the West and the East, it is useful to examine the shift of economic power from the West to the East. After World War II, the first to rise was Japan, followed by the Four Asian Tigers. However, it was not until China's rise, mainly due to her 'reform and opening-up' in the past 40 years, that the world's economic center of gravity shifted from the Atlantic to the Pacific. This is why today's Belt and Road Initiative seems so intuitive - the Silk Roads, by land and sea, actually existed 2,000 years ago, so a restoration of these trade routes is not too much of a stretch of the imagination. It is simply a revival of trade and cultural interactions that existed two millennia ago. In this sense, even if China's President Xi Jinping had not proposed the Belt and Road Initiative, the same concept would have been brought forward by other nations sooner or later.

\section{Three Major Sources of Conflict}

This seismic shift in power will naturally result in some friction and possibly even conflict. I believe there are three major sources of conflict that currently plague U.S.China relations: economics and trade, science and technology, and currency. I reckon that the current trade disputes between the United States and China are only a tertiary conflict, while the primary and secondary concerns are technological superiority leading to military supremacy, and currency domination. Recently, technology has become a far more serious issue and has replaced trade as the main battle ground.

The first source of conflict, economic and trade competition, is not a dominant concern. Disagreements in economics and trade are commonplace. It is the easiest problem to resolve between the two nations, and there is much room for negotiation.

The second major conflict is currency domination. Since the United States overtook the United Kingdom somewhere around 1890, the U.S. dollar gradually, particularly after World War II, become the world's default currency. This has enabled the 
United States to take out loans time and again, but the question is - can this pattern of borrowing last forever? I do believe that the U.S. dollar will remain the global currency for quite some time, but we cannot deny the increasing importance of the Chinese Yuan, especially since China has now become the world's second largest economy.

To a large extent, America's economy relies on the U.S. dollar being by far the world's most significant reserve currency. Her ability to print an inordinate amount of the greenback enables the United States to live beyond her means. It is not a stretch to say that much of the global financial system is built on the confidence on the U.S. dollar. It does not take too much imagination to see how this confidence could be shaken. When this happens, everyone will suffer, but none so much as the United States. However, we must recognize one important fact-ultimately the only country that can bring down the U.S. dollar is the United States herself.

The primary conflict, and perhaps the most contentious, is competition in science and technology. Technological advances are made with each passing day: from GPS to quantum computing and a lot more, competition has brought about innovation and invention in many areas, including the Internet, which is one of the biggest areas of competition. At the heels of technology advances is the invention and proliferation of weapons. In the past few years, the United States has targeted Huawei, China's largest hardware company. One theory I have is that the United States' monopoly in spying is being threatened.

\section{China and US Can Learn How to Live With Each Other}

China and the United States seem to be at each other's throats with a tête-à-tête that can often become intense and at times even bellicose. However, I am not too pessimistic about the future of U.S.-China relations. Let me illustrate why.

First, China simply does not want to get into a major conflict with any country, least of all the United States. I also do not believe that the United States would be able to beat China to submission, which may well be the unspoken intention of Washington, D.C. If so, the best alternative for the United States is to work with China. As the number two, China is not a challenger, except in the minds of the number one, the United States, nor does the former have the ability to be a global leader. In fact, China is very happy to play second fiddle to the United States. Sadly, the United States cannot accept that. America has never been good at compromising or at diplomacy, since she can always resort to her military and economic might.

In the coming few years, China will focus, as before, on her own domestic development. After all, she can no longer rely on the international community for her further growth. China will not close her doors, because she knows that she needs the world, just as the world needs her. However, even if there is an opportunity, Beijing will not take the initiative to play too big a role in the global arena, except to protect her own core interests. The United States is afraid that China will rise to become another hegemon like the United States was, and still is - a bully. This is rather ironic, 
considering how much of the rest of the world views the United States as a bully. I do not believe China would take this path, but it also seems impossible to convince my Western friends to think likewise.

Second, there are many global issues where the world needs the United States and China to work together to resolve, including climate change, environment, immigration, economic, international trade, financial security, etc.

Finally, at this point in China's development, a major conflict between China and the United States is untenable for both countries. 40 years ago, China metaphorically stood at $1.6 \mathrm{~m}$, while the United States towered over her at $2.2 \mathrm{~m}$. Back then, if these two friends got mad at each other, all the taller one had to do was give the shorter one a slap. 30 years ago, China grew to around $1.75 \mathrm{~m}$, yet a single punch would still knock her down. A decade ago, China stood at $1.9 \mathrm{~m}$, so it would take a few blows to put her in her place. Today, the United States is still $2.2 \mathrm{~m}$, but China has hit the 2-m mark, which should make the United States think twice before picking a fight. If the United States is smart, she will not pick a fight with China as any physical conflict would deeply hurt both sides and could be fatal for everyone. This does not mean I view China's system as perfect. Of course, like the West, stupid things can happen. But the point made here is that if there really is a fight, both sides will lose. The United States and China are restrained by the balance of power between the two nations.

\section{Change is Coming, but Everything Will Be Alright}

The world has arrived at another pivotal moment. What happens today will change the course of the world in the coming few decades. It is akin to the onset of the Cold War after World War II, China's opening up to the world, and the fall of the Berlin Wall. For China, these three globally significant events draw parallels with three defining moments: the Korean War, U.S. President Nixon's visit, and the June 4,1989 , incident that took place the same year as the fall of the Berlin Wall. Each of these events were catalysts that changed the world.

As we contemplate at this pivotal point in history, we are experiencing popular attitudes deeply embedded in Chinese and American thinking. Many Chinese believe that the United States is on the decline. I disagree. Similarly, a good number of my American friends think that China will implode, especially with the pressures applied from the outside. I also seriously doubt this. I believe that both nations will be fine. This is why I am at ease in both places, as I am also in many other parts of the world. However, China must keep a very cool head. Chinese leaders have been very calm in the past 40 years, from the Foreign Ministry to the Ministry of Commerce. I believe that they will continue to be, and therefore the future will not as bad as many people think, especially the millions of people in the United States. If we learn from history and do what we should do, we can avoid obvious pitfalls and work toward a bright future for a co-prospering multilateral world. 
Ronnie C. Chan is the Chair of Hang Lung Group Limited and its subsidiary Hang Lung Properties Limited. He received his MBA from the University of Southern California and honorary doctorate degrees from The Hong Kong University of Science and Technology, The Chinese University of Hong Kongand Tel Aviv University. He actively involved with non-profits, philanthropic endeavors, and educational organizations, as Chair Emeritus of the Asia Society and Chairman of its Hong Kong Center, and Co-Founder and Chair of the Centre for Asian Philanthropy and Society to name just a few. He is a Fellow of the American Academy of Arts and Sciences.

Open Access This chapter is licensed under the terms of the Creative Commons AttributionNonCommercial-NoDerivatives 4.0 International License (http://creativecommons.org/licenses/bync-nd/4.0/), which permits any noncommercial use, sharing, distribution and reproduction in any medium or format, as long as you give appropriate credit to the original author(s) and the source, provide a link to the Creative Commons license and indicate if you modified the licensed material. You do not have permission under this license to share adapted material derived from this chapter or parts of it.

The images or other third party material in this chapter are included in the chapter's Creative Commons license, unless indicated otherwise in a credit line to the material. If material is not included in the chapter's Creative Commons license and your intended use is not permitted by statutory regulation or exceeds the permitted use, you will need to obtain permission directly from the copyright holder.

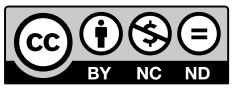

